\title{
1 Holocene glaciation in the Rwenzori Mountains, Uganda
}

2 Margaret S. Jackson ${ }^{1 *}$, Meredith A. Kelly ${ }^{1}$, James M. Russell ${ }^{2}$, Alice M. Doughty ${ }^{3}$, Jennifer A.

3 Howley $^{1 \wedge}$, Susan R.H. Zimmerman ${ }^{4}$, Bob Nakileza ${ }^{5}$

4

5 1. Earth Sciences, Dartmouth College, Hanover, NH, United States

6 2. Earth, Environmental, and Planetary Sciences, Brown University, Providence, RI United

7 States

8 3. Geology, Bates College, Lewiston, ME

9 4. Center for Accelerator Mass Spectrometry, Lawrence Livermore National Laboratory,

10 Livermore, CA United States

11 5. Mountain Resource Centre, Makerere University, Kampala, Uganda

12 *Current address: School of Geography, Archaeology, and Irish Studies, National University of

13 Ireland Galway, Galway, Ireland

$14 \wedge^{\wedge}$ Current address: New Hampshire Department of Health and Human Services, Concord, NH,

15 United States

16 Correspondence to: Margaret S. Jackson (margaret.jackson@nuigalway.ie) 


\section{Abstract}

25 Tropical glaciers are retreating rapidly, threatening alpine ecosystems across the low latitudes.

26 Understanding how tropical glaciers responded to past periods of warming is crucial for

27 predicting and adapting to future climate change, yet relatively little is known about glacial

28 fluctuations in tropical regions during the recent past (i.e., the Holocene Epoch). This is

29 particularly true in the African tropics, where data constraining the timing and magnitude of

30 Holocene glacial fluctuations in the region are sparse and where temperatures during the Middle

31 Holocene were perhaps as warm as or warmer than today. Here we present new beryllium-10

32 surface-exposure ages that constrain Holocene glacial extents in the equatorial Rwenzori

33 Mountains, Uganda. These results document rapid Early Holocene ( 11.7-8.2 ka) glacial retreat

34 in two separate catchments and indicate that Late Holocene ( 4.2 ka-present) deposits mark the

35 greatest expansion of Rwenzori glaciers during the last $\sim 11 \mathrm{ka}$. Holocene glacial fluctuations

36 elsewhere in tropical Africa and in tropical South America are broadly similar to those in the

37 Rwenzori, with most tropical glaciers retreating rapidly during the Early Holocene and

38 remaining near or inboard of their Late Holocene positions through much of Holocene time. The

39 similarity of Holocene glacial fluctuations across the tropics implies that low-latitude glaciers

40 responded to a common forcing mechanism, most likely temperature. Although the drivers of

41 Holocene temperature changes in the tropics remain enigmatic, these data help constrain the

42 expression of tropical temperature changes in the low latitudes. 
The ongoing, coherent retreat of Earth's alpine glaciers is unique within the Holocene

49 Epoch ( 11.7 ka-present; Walker et al., 2012) and emblematic of anthropogenic warming

50 (Solomina et al., 2015). The loss of alpine glaciers is of particular concern in the tropics, where

51 high-elevation regions are warming at a rate twice the global average (Vuille et al., 2008).

52 Tropical glaciers are a primary source of freshwater and are a fundamental component of

53 regional economies, underpinning agriculture, hydropower, and tourism (Bradley et al., 2006;

54 Chevallier et al., 2011). Accurately projecting the response of glaciers to future climate change is

55 thus crucial for effective community response and adaptation (Stocker et al., 2013), and these

projections rely on robust understanding of the sensitivity of tropical glaciers to past climate

57 conditions.

58 Tropical glaciers respond to changes in both temperature and precipitation, although the

59 relative influence of these forcings depends upon a glacier's unique climatic setting (Sagredo et

60 al., 2014). Recent work to reconstruct past glacial fluctuations in tropical South America

61 indicates that glaciers there were near or inboard of their Late Holocene ( 4.2 ka-present; Walker

62 et al., 2012) maxima during much of the Holocene Epoch (Jomelli et al., 2014; Solomina et al.,

63 2015; Stansell et al., 2017). Although relatively little is known about Holocene glacial

64 fluctuations in the African tropics (Kaser and Osmaston, 2002; Solomina et al., 2015), recently

65 produced terrestrial paleotemperature reconstructions provide greater paleoclimatic context for

66 understanding past changes in tropical African glacial extent (Weijers et al., 2007; Tierney et al.,

67 2008; Woltering et al., 2011; Loomis et al., 2012, 2017). Of particular interest is the response of

68 glaciers to climate conditions during the Middle ( 8.2-4.2 ka) and Early ( 11.7-8.2 ka) Holocene

69 Epoch (Walker et al,. 2012), when temperatures in tropical Africa may have been similar to or 
70 higher than modern (Ivory et al., 2017 and references therein). Determining when and how

71 glaciers in the African tropics fluctuated during past warm periods provides crucial information

72 for assessing whether, or how long, tropical glaciers may persist under future warming scenarios.

73 Here we present new data from the equatorial Rwenzori Mountains of Uganda $\left(0.3^{\circ} \mathrm{N}\right.$,

$7430.0^{\circ} \mathrm{E}$; Figure 1) that constrain the extent of glaciers in two separate valleys during the

75 Holocene. These data include twelve beryllium-10 $\left({ }^{10} \mathrm{Be}\right)$ surface-exposure ages of glacial

76 landforms which provide evidence of past glacial extents in the Rwenzori during Holocene time.

77 We then compare the Rwenzori glacial chronology with records of East African glaciation and

78 paleoclimate to assess both the potential drivers of past glacial fluctuations as well as the

79 response of these glaciers to changes in Holocene climate.

80 


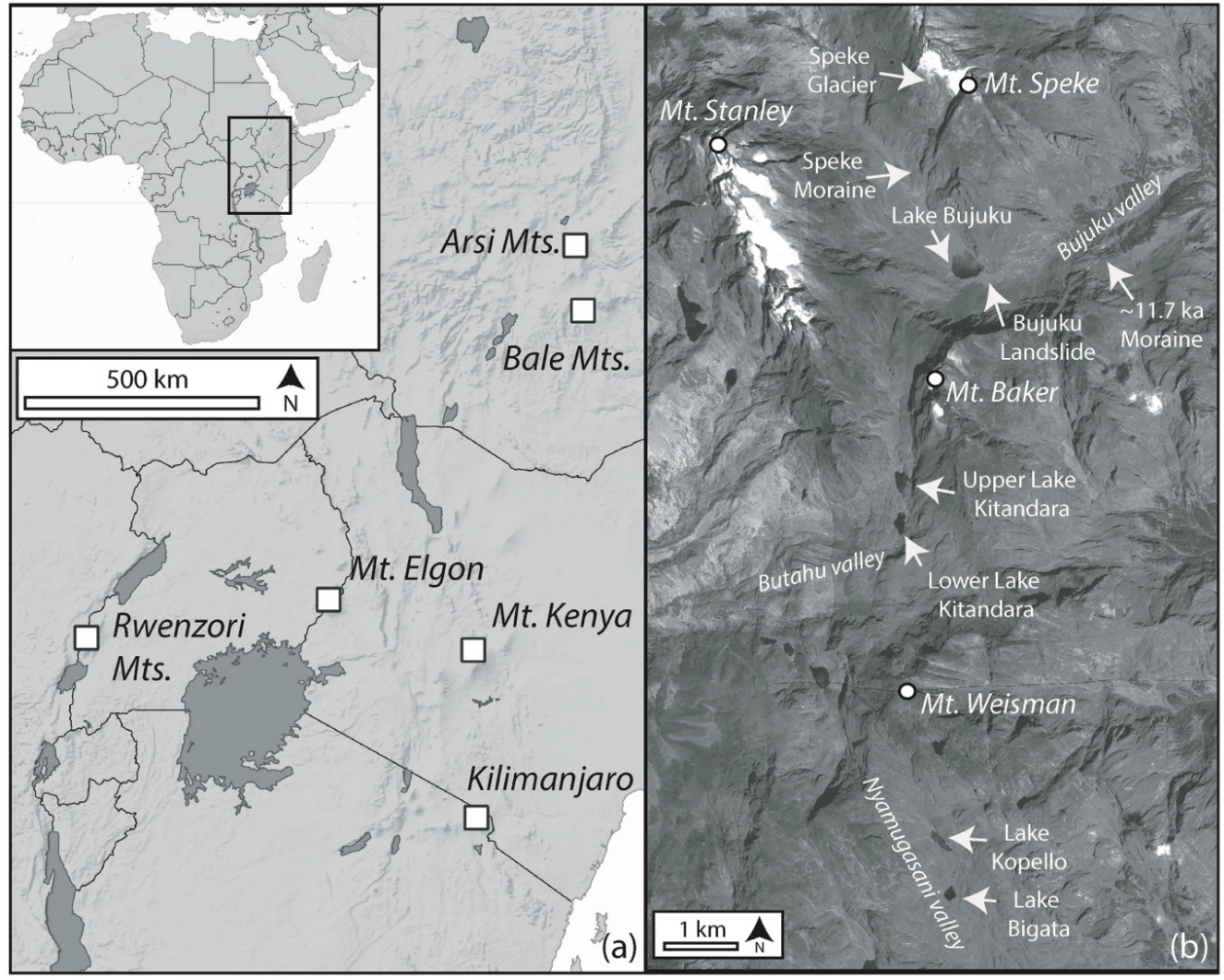

Figure 1. Tropical East Africa and the Rwenzori Mountains. (a) The Rwenzori Mountains, Kilimanjaro, and Mt. Kenya are the only three still-glacierized sites in East Africa. Mt. Elgon in Uganda and the Arsi and Bale Mountains in Ethiopia also host glacial deposits, though are no longer glacierized. (b) Worldview-1 satellite image of the central Rwenzori massif and locations mentioned in the text. Glaciers persist in the Rwenzori on Mt. Stanley, Mt. Speke, and Mt. Baker. Although no longer glacierized, the former Thomson Glacier occupied the peak of Mt. Weisman during the early $20^{\text {th }}$ century.

\section{Background}

The Rwenzori Mountains are an uplifted horst of crystalline bedrock and are an extreme example of rift shoulder uplift (McConnell et al., 1953; Ring, 2008). Mt. Stanley, the highest point in the range, reaches an elevation of 5,109 meters above sea level (m asl) and, with Mt. Speke and Mt. Baker, is one of three still-glacierized peaks in the Rwenzori (Figure 1). The first quantitative observations of Rwenzori glaciers were made in the early 20th century (Abruzzi, 
95 1907). Rwenzori glaciers have retreated markedly since then, decreasing in area from $\sim 6.5$ to

$960.96 \mathrm{~km}^{2}$ between 1906 and $2003 \mathrm{CE}$ and losing an estimated 50\% of their areal extent between

971987 and 2003 CE (Taylor et al., 2006). Modern glaciers in the Rwenzori occur only above

$98 \sim 4,400 \mathrm{~m}$ asl and are predicted to disappear within the coming decades (Kaser and Osmaston,

99 2002; Taylor et al., 2006).

100 Although at present glaciers occupy only the highest peaks (Figure 1), the Rwenzori host

101 glacial deposits that attest to more extensive glaciation during and since the last ice age.

102 Osmaston $(1965 ; 1989)$ grouped moraines in the Rwenzori into distinct glacial stages based on

103 their relative weathering, stratigraphic position, and morphology. The 'Omurubaho' stage

104 moraines occur at elevations $\sim 3,600-4,000 \mathrm{~m}$ asl and feature $\sim 3-30 \mathrm{~m}$ relief above the valley

105 floors (Osmaston, 1989). Osmaston (1989) estimated these moraines to have been deposited

106 during the Early Holocene. Recent ${ }^{10} \mathrm{Be}$ dating of Omurubaho stage moraines in the Bujuku and

107 Nyamugasani valleys indicates deposition during late-glacial ( 15.0-11.7 ka) and Early

108 Holocene time (Jackson et al., in review). The 'Lac Gris' stage moraines (Osmaston, 1989) are

109 located up valley and stratigraphically inboard of the Omurubaho stage moraines. Lac Gris stage

110 moraines are predominantly low-relief features (1-2 $\mathrm{m}$ above the valley floors) and are within

$111 \sim 100$ m of observed 1906 CE ice extents (Abruzzi, 1907). Osmaston (1989) estimated Lac Gris

112 stage moraines to be 700-100 years old. Based on lichenometry, Bergström (1955) suggested

113 that Lac Gris stage moraines observed near the margin of Elena Glacier on Mt. Stanley date to

$114 \sim 1750 \mathrm{CE}$. However, the rate at which lichens colonize rock surfaces in the Rwenzori is

115 unconstrained (Osmaston et al., 1989) and the ultimate age of pre-observation Lac Gris moraines

116 remains undetermined. 
117 Livingstone (1967) obtained radiocarbon ages of lake sediments that provide minimum

118 limits on the timing of deglaciation at several locations in the Rwenzori. In the Butahu valley,

119 dated organic sediments within a horizon roughly one meter above presumed basal silts in Upper

120 Lake Kitandara (4,000 m asl; Figure 1) yield a radiocarbon age of $\sim 7.7$ cal kyr BP (Livingstone,

121 1967). This provides a minimum-limiting age for glacial recession past this location in the

122 valley. In the Bujuku valley, one radiocarbon age from a layer of gravel-rich peat in a sediment

123 core from Lake Bujuku (3,920 m asl) yields an age of 3.1 cal kyr BP (Livingstone et al, 1967).

124 However, this core did not recover the complete sedimentary succession from the lake and,

125 therefore, may significantly postdate the onset of post-glacial sedimentation in the lake.

126 Rwenzori glacial fluctuations that occurred between the Early Holocene and the (near) historical

127 period are largely unconstrained. A sediment core from Lower Lake Kitandara $(\sim 4,000 \mathrm{~m}$ asl)

128 indicates changes in lake water chemistry at the turn of the 18th century consistent with greater

129 glacier meltwater flux to the lake, although with no corresponding changes in pollen or diatom

130 assemblages (McGlynn et al., 2010). High-resolution analyses of clastic sediment input to

131 numerous Rwenzori alpine lakes indicate that recent historical glacial recession began about

1321870 CE (Russell et al., 2009).

133 Evidence from elsewhere in tropical East Africa suggests that glaciers across the region 134 were near or inboard of their maximum Late Holocene extents for much of Holocene time.

135 Radiocarbon ages from lake sediments in the Bale Mountains and on Mt. Arsi in the Ethiopian

136 Highlands, as well as from Mt. Elgon in Uganda, indicate that glaciers at these sites were inboard

137 of their late-glacial extents, and perhaps had ablated completely, by the Early Holocene

138 (Hamilton and Perrot, 1982; Tiercelin et al., 2008). In Tanzania, the persistence of Holocene ice

139 cover on Kilimanjaro is a subject of ongoing debate. Multiple studies show that the Kilimanjaro 
140 Ice Cap has become less extensive over the last $\sim 1 \mathrm{ka}$, although whether the ice cap may have

141 ablated completely at some point during the Holocene and later re-nucleated is uncertain

142 (Thompson et al., 2002; Kaser et al., 2010; Thompson et al., 2011; Noell et al., 2014). Recent

143 radiocarbon dating of dust and soil horizons within the ice cap suggests a period of net ice cap

144 ablation occurred prior to $4 \mathrm{ka}$, followed by net accumulation during the Late Holocene that

145 persisted until near-historical time when recent recession began (Gabrielli et al., 2014).

146 At Mt. Kenya, chlorine-36 $\left({ }^{36} \mathrm{Cl}\right)$ surface-exposure dating of moraines and glacially

147 molded bedrock in the Teleki Valley indicates that glaciers retreated from their Early Holocene

148 maximum extents by $\sim 10 \mathrm{ka}$ and that the modern Lewis Glacier reached its maximum Late

149 Holocene extent 200 years ago (Shanahan and Zreda, 2000). In contrast to the existing evidence

150 for limited Middle Holocene glacial expansion in the Rwenzori and on Kilimanjaro, radiocarbon

151 ages of Mt. Kenya’s Naro Moru Tarn moraine dam, located $\sim 250 \mathrm{~m}$ down valley of the $\sim 200$

152 year old Lewis Glacier moraine, suggest a glacial advance occurred in the Teleki Valley between

$153 \sim 6.9$ and 4.7 cal yr BP (Johansson and Holmgren, 1985; Karlen et al., 1999). Although disputed

154 (Mahaney et al., 1989), radiocarbon ages from Thomson Tarn in the Hobley Valley also suggest

155 a Middle Holocene glacial advance on Mt. Kenya between 7.1 and 6.2 cal yr BP (Perrot, 1982).

156 In addition, clastic sediment fluxes to high alpine lakes on Mt. Kenya indicate more dynamic,

157 erosive glacial activity after $\sim 5$ cal yr BP (Karlen et al., 1999), although the extent of

158 corresponding glacial margins throughout this period is not known.

This study aims to establish the timing of Holocene glacial fluctuations in the Rwenzori

160 Mountains and compare directly the Holocene Rwenzori glacial chronology with records of

161 glaciation and paleoclimate elsewhere in tropical East Africa. Prior work mapping and dating

162 Last Glacial Maximum (LGM) and late-glacial Rwenzori glacial deposits lends crucial temporal 
and spatial context for the Holocene chronology (Kelly et al., 2014; Jackson et al., 2019; Jackson

164 et al., in review) and allows a more robust comparison of the Rwenzori glacial record with

165 records of past regional climate conditions.

166

167

\section{Study Sites}

168

We focused our study within the Bujuku and Nyamugasani valleys, two independent

catchments in the Rwenzori that contain Holocene-age glacial deposits amenable for ${ }^{10} \mathrm{Be}$ dating and for which there is pre-existing numerical age control on pre- or Early Holocene glacial deposits (Jackson et al., 2019; Jackson et al., in review).

\subsection{Bujuku valley}

The modern Speke Glacier occupies the south-facing peak of Mt. Speke (4,890 m asl) near the head of the Bujuku valley (Figure 1,2). Although today the glacial terminus occurs at $\sim 4,600 \mathrm{~m}$ asl, in $1958 \mathrm{CE}$ the glacier extended down slope to $\sim 4,350 \mathrm{~m}$ asl (Whittow et al., 1963). Lac Gris stage deposits occur on Mt. Speke between 4,000 and 4,500 m asl (Osmaston, 1989), including a Lac Gris stage moraine $300 \mathrm{~m}$ downslope from the 1958 CE glacial extent (Osmaston, 1989)(Figure 2). Observations by Abruzzi (1907) indicate that ice had abandoned this Lac Gris stage moraine prior to $1906 \mathrm{CE}$, though the precise timing of retreat is not known (Whittow, 1963). stage moraines, and the innermost (i.e., farthest up valley) of these dates to $11.7 \mathrm{ka}$ (Jackson et al., in review). There are no moraines in the valley between the $\sim 11.7$ ka moraine and the Lac

185 Gris stage deposits on Mt. Speke. Approximately $1.5 \mathrm{~km}$ up valley from the $\sim 11.7 \mathrm{ka}$ moraine, 
186 the outlet of Lake Bujuku is dammed by a landslide that originated on the north-facing slope of

187 Mt. Baker (Figure 1). This landslide is dated to $\sim 11 \mathrm{ka}$ and shows no evidence of having been

188 impeded or reworked by ice either during or subsequent to deposition (Cavagnaro, 2017).

189 Therefore, it is likely that the landslide was emplaced after ice retreated up valley and the age

$190(\sim 11 \mathrm{ka})$ is a minimum-limiting age for deglaciation of the valley floor at this location (Jackson

191 et al., in review).

192

193

\subsection{Nyamugasani valley}

Mt. Weisman (4,620 m asl) marks the head of the Nyamugasani valley (Figure 1,2).

195 Although no longer glacierized, the former Thomson Glacier occupied a cirque on the south-

196 facing slope of the peak until the mid-20 $0^{\text {th }}$ century (Osmaston and Pasteur, 1972). Omurubaho-

197 stage moraines occur in the Nyamugasani valley between $\sim 3,800$ and 4,000 $\mathrm{m}$ asl. The innermost

198 (i.e., farthest up valley) Omurubaho moraine is dated to $\sim 11.2 \mathrm{ka}$ and dams Lake Bigata $(\sim 4,000$

$199 \mathrm{~m}$ asl)(Jackson et al., in review). There are no moraines between Lake Bigata and the peak of Mt.

200 Weisman, although glacially transported boulders are ubiquitous on the valley

201 floor. Approximately $0.5 \mathrm{~km}$ up valley from the $\sim 11.2 \mathrm{ka}$ moraine, four boulders on a bedrock

202 rise at the outlet of Lake Kopello ( 4,020 m asl) yield ages between $\sim 12.1$ and $10.5 \mathrm{ka}$,

203 indicating continued recession of ice in the valley after $\sim 11 \mathrm{ka}$ (Jackson et al., in review). 

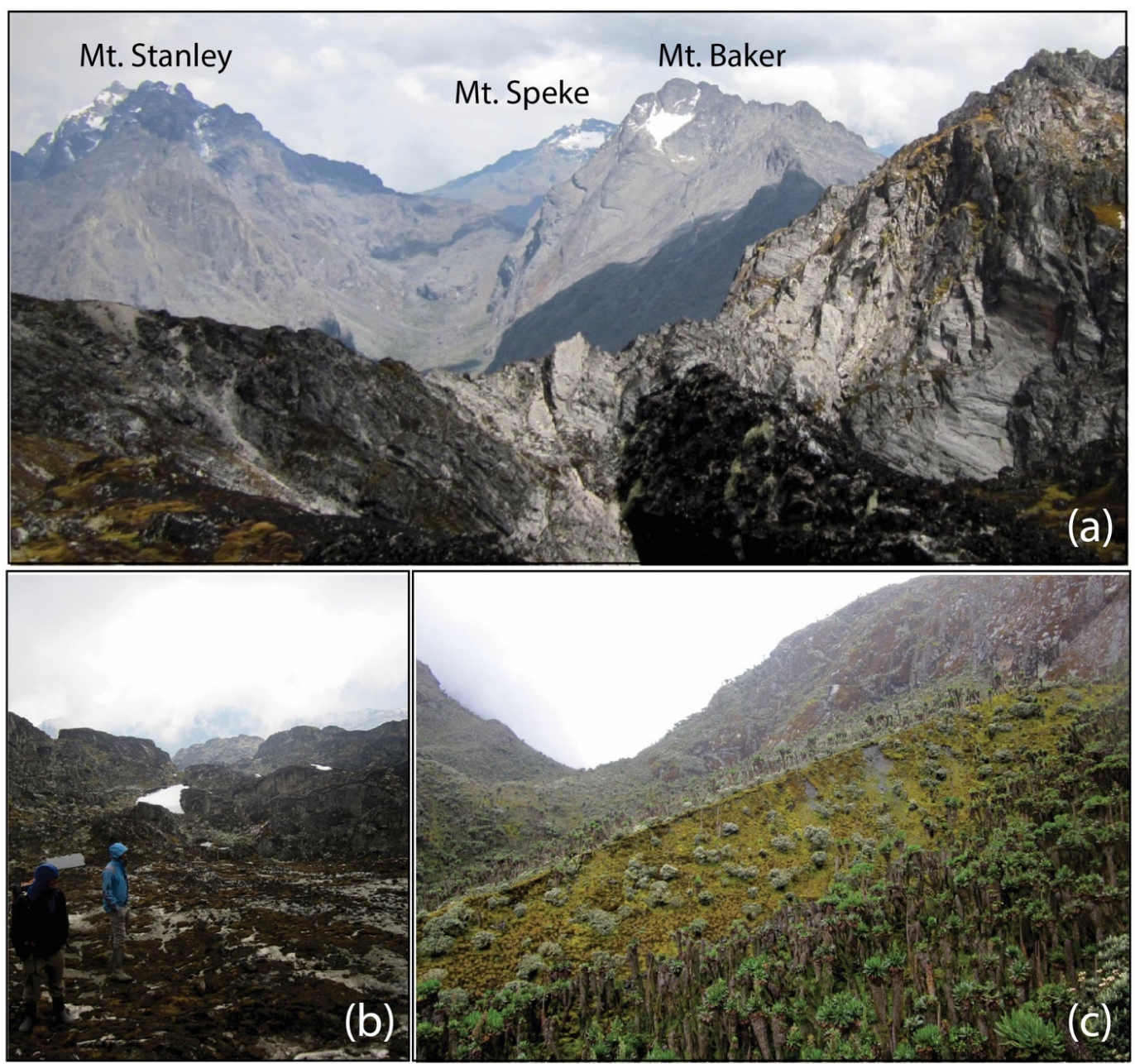

Figure 2. Glacial features in the central Rwenzori Mountains. (a) A view toward the north from the peak of Mt. Weisman. Mt. Stanley, Mt. Speke, and Mt. Baker are the three still-glacierized peaks in the Rwenzori. Above 4,000 $\mathrm{m}$ asl, the Rwenzori are dominated by bare bedrock with some lichen and moss cover. (b) A view down valley, toward the south, from the unoccupied cirque on Mt. Weisman that once held the former Thomson Glacier. (c) The right-lateral Speke moraine beneath Speke Glacier features a sharp crest and steep ice-proximal slope. View is 


\section{Methods}

We conducted three field seasons in the Rwenzori between 2012 and 2016. While in the

218 field we classified glacial-geomorphic features based on their morphology, stratigraphic position,

219 and degree of weathering and mapped these features onto WorldView-1 0.5-m resolution

220 satellite imagery. We collected samples for ${ }^{10} \mathrm{Be}$ dating from boulders on moraines, boulders on

221 bedrock, and from bedrock surfaces using a hammer and chisel and the drill-and-blast method of

222 Kelly (2003). We took care to sample boulders that showed no indication of post-depositional

223 movement and, where possible, surfaces with no dip in order to minimize topographic shielding

224 correction uncertainties. We recorded sample locations with a handheld GPS $( \pm 3 \mathrm{~m}$ vertical, \pm 1

225 m horizontal), determined topographic shielding using a clinometer, and measured sample

226 surface dip and dip direction, if applicable, with a handheld compass (Table 1).

\begin{tabular}{|c|c|c|c|c|c|c|c|c|c|c|c|c|}
\hline \multicolumn{13}{|c|}{ Table 1: Rwenzori Sample Information } \\
\hline & & & & & & & & & & & & \\
\hline \multicolumn{13}{|c|}{ Bujuku Valley } \\
\hline \multirow[t]{2}{*}{ Map ID } & Sample ID & Landform & Latitude & Longitude & Elev. & Atm. & Thickness & Density & Shielding & Erosion & $10-B e$ & $\pm 10-B e$ \\
\hline & & & $(D D)$ & $(D D)$ & $(m)$ & & $(\mathrm{cm})$ & $(\mathrm{g} / \mathrm{cm} 3)$ & & $(\mathrm{mm} / \mathrm{yr})$ & (atoms $/ g$ ) & (atoms $/ g$ ) \\
\hline 1 & $R Z-12-21$ & Speke moraine & 0.38750 & 29.88821 & 4095 & std & 1.5 & 2.65 & 0.909 & 0 & $9.29 \mathrm{E}+03$ & $7.84 \mathrm{E}+02$ \\
\hline 2 & $R Z-12-22$ & Speke moraine & 0.38768 & 29.88816 & 4046 & std & 1.2 & 2.65 & 0.909 & 0 & $6.96 \mathrm{E}+03$ & $4.80 E+02$ \\
\hline 3 & $R Z-12-24$ & Speke moraine & 0.38768 & 29.88816 & 4046 & std & 1.3 & 2.65 & 0.909 & 0 & $1.02 \mathrm{E}+04$ & $5.07 E+02$ \\
\hline 4 & RZ-12-25 & Speke moraine & 0.38768 & 29.88816 & 4046 & std & 1.5 & 2.65 & 0.909 & 0 & $1.17 \mathrm{E}+04$ & $3.87 E+02$ \\
\hline \multicolumn{13}{|c|}{ Nyamugasani Valley } \\
\hline \multirow[t]{2}{*}{ Map ID } & Sample ID & Landform & Latitude & Longitude & Elev. & Atm. & Thickness & Density & Shielding & Erosion & $10-B e$ & $\pm 10-B e$ \\
\hline & & & $(D D)$ & $(D D)$ & $(m)$ & & $(\mathrm{cm})$ & $(\mathrm{g} / \mathrm{cm} 3)$ & & $(\mathrm{mm} / \mathrm{yr})$ & (atoms $/ g$ ) & (atoms $/ g$ ) \\
\hline 5 & $R Z-15-10$ & Perched boulder & 0.32265 & 29.89128 & 4397 & std & 4.0 & 2.65 & 0.976 & 0 & $3.78 \mathrm{E}+05$ & $3.56 \mathrm{E}+03$ \\
\hline 6 & RZ-15-11 & Perched boulder & 0.32263 & 29.89132 & 4400 & std & 2.0 & 2.65 & 0.976 & 0 & $3.60 \mathrm{E}+05$ & $2.50 E+03$ \\
\hline 7 & RZ-15-09 & Perched boulder & 0.32385 & 29.89034 & 4431 & std & 3.0 & 2.65 & 0.983 & 0 & $3.51 \mathrm{E}+05$ & $3.79 E+03$ \\
\hline 8 & RZ-15-07 & Perched boulder & 0.32589 & 29.88928 & 4488 & std & 1.9 & 2.65 & 0.989 & 0 & $1.51 \mathrm{E}+05$ & $1.50 \mathrm{E}+03$ \\
\hline 9 & RZ-15-08 & Perched boulder & 0.32601 & 29.88953 & 4498 & std & 2.0 & 2.65 & 0.99 & 0 & $2.19 E+05$ & $4.14 \mathrm{E}+03$ \\
\hline 10 & RZ-15-01 & Cirque Bedrock & 0.32793 & 29.88877 & 4509 & std & 1.9 & 2.65 & 0.969 & 0 & $1.66 \mathrm{E}+05$ & $1.81 \mathrm{E}+03$ \\
\hline 11 & RZ-15-02 & Cirque Bedrock & 0.32786 & 29.88887 & 4526 & std & 1.4 & 2.65 & 0.97 & 0 & $1.69 \mathrm{E}+05$ & $1.84 \mathrm{E}+03$ \\
\hline 12 & RZ-15-03 & Cirque Bedrock & 0.32781 & 29.88871 & 4536 & std & 2.8 & 2.65 & 0.97 & 0 & $1.89 \mathrm{E}+05$ & $1.68 \mathrm{E}+03$ \\
\hline
\end{tabular}

229 Table 1. Geographic data and sample characteristic information for Rwenzori samples. 

version 3 of the online calculator described by Balco et al. (2008 and subsequently updated) with a high-altitude, low-latitude production rate (Kelly et al., 2015) and time-invariant scaling

\begin{tabular}{|c|c|c|c|c|c|c|c|c|c|c|c|}
\hline \multicolumn{12}{|c|}{ Table 2: Rwenzori Sample Chemistry } \\
\hline & & & & & & & & & & & \\
\hline \multicolumn{12}{|c|}{ Bujuku Valley } \\
\hline \multirow[t]{2}{*}{ Map ID } & Sample ID & Landform & Cathode ID & Quartz & Carrier wt. & Carrier Conc. & Sample & \pm Sample & Process Blank & Blank & \pm Blank \\
\hline & & & & (g) & $(m g)$ & (ppm) & $(10-B e / 9-B e)$ & $(10-B e / 9-B e)$ & Cathode ID & $(10-B e / 9-B e)$ & $(10-B e / 9-B e)$ \\
\hline 1 & $R Z-12-21$ & Speke moraine & BE43754 & 16.1727 & 0.2013 & 0.973 & $1.14775 \mathrm{E}-14$ & $9.69152 \mathrm{E}-16$ & BE43758 & $1.63761 \mathrm{E}-15$ & $3.53685 \mathrm{E}-16$ \\
\hline 2 & RZ-12-22 & Speke moraine & BE43755 & 32.3243 & 0.2006 & 0.973 & $1.72402 \mathrm{E}-14$ & $1.19007 \mathrm{E}-15$ & BE43758 & $1.63761 \mathrm{E}-15$ & $3.53685 \mathrm{E}-16$ \\
\hline 3 & RZ-12-24 & Speke moraine & BE43756 & 23.8116 & 0.2013 & 0.973 & $1.85318 \mathrm{E}-14$ & $9.2237 \mathrm{E}-16$ & BE43758 & $1.63761 \mathrm{E}-15$ & $3.53685 \mathrm{E}-16$ \\
\hline 4 & $R Z-12-25$ & Speke moraine & BE43757 & 40.0454 & 0.2010 & 0.973 & 3.59382E-14 & $1.18435 \mathrm{E}-15$ & BE43758 & $1.63761 \mathrm{E}-15$ & $3.53685 E-16$ \\
\hline \multirow{2}{*}{\multicolumn{12}{|c|}{ Nyamugasan }} \\
\hline & & & & & & & & & & & \\
\hline \multirow[t]{2}{*}{ Map ID } & Sample ID & Landform & Cathode ID & Quartz & Carrier wt. & Carrier Conc. & Sample & \pm Sample & Process Blank & Blank & \pm Blank \\
\hline & & & & (g) & $(m g)$ & (ppm) & $(10-B e / 9-B e)$ & $(10-B e / 9-B e)$ & Cathode ID & $(10-B e / 9-B e)$ & $(10-B e / 9-B e)$ \\
\hline 5 & RZ-15-10 & Perched boulder & BE39810 & 100.945 & 0.0907 & 1.338 & $4.70348 \mathrm{E}-12$ & $4.43266 \mathrm{E}-14$ & BE39812 & $3.81273 \mathrm{E}-15$ & $6.15885 \mathrm{E}-16$ \\
\hline 6 & RZ-15-11 & Perched boulder & BE39811 & 102.028 & 0.091 & 1.338 & 4.51587E-12 & $3.13429 \mathrm{E}-14$ & BE39812 & 3.81273E-15 & $6.15885 \mathrm{E}-16$ \\
\hline 7 & RZ-15-09 & Perched boulder & BE39809 & 100.573 & 0.0916 & 1.338 & $4.30701 \mathrm{E}-12$ & $4.65808 \mathrm{E}-14$ & BE39812 & $3.81273 \mathrm{E}-15$ & $6.15885 \mathrm{E}-16$ \\
\hline 8 & RZ-15-07 & Perched boulder & BE39808 & 101.292 & 0.0881 & 1.338 & 1.94507E-12 & 1.93123E-14 & BE39812 & $3.81273 \mathrm{E}-15$ & $6.15885 E-16$ \\
\hline 9 & $R Z-15-08$ & Perched boulder & BE40319 & 12.014 & 0.1650 & 1.340 & $1.78244 \mathrm{E}-13$ & $3.36358 \mathrm{E}-15$ & BE40308 & $7.21905 E-16$ & 1.41075E-16 \\
\hline 10 & $R Z-15-01$ & Cirque Bedrock & BE39531 & 100.57 & 0.0961 & 1.337 & $1.94043 \mathrm{E}-12$ & 2.11829E-14 & BE39534 & 6.99989E-15 & $5.814 \mathrm{E}-16$ \\
\hline 11 & $R Z-15-02$ & Cirque Bedrock & BE39532 & 100.79 & 0.0967 & 1.337 & $1.97014 \mathrm{E}-12$ & $2.14812 \mathrm{E}-14$ & BE39534 & $6.99989 \mathrm{E}-15$ & $5.814 \mathrm{E}-16$ \\
\hline 12 & RZ-15-03 & Cirque Bedrock & BE39533 & 101.33 & 0.0930 & 1.337 & $2.30326 \mathrm{E}-12$ & 2.04419E-14 & BE39534 & $6.99989 \mathrm{E}-15$ & $5.814 \mathrm{E}-16$ \\
\hline
\end{tabular}

Table 2. Processing data and sample chemistry for all Bujuku and Nyamugasani valley samples. 
248 We do not correct ${ }^{10} \mathrm{Be}$ ages for the potential impacts of snow cover or vegetation. Snow 249 does not persist for considerable lengths of time at the sample elevations due to warm daytime

250 temperatures and intense solar radiation. Vegetation in the Rwenzori Mountains above $\sim 4,000 \mathrm{~m}$

251 asl is sparse (Osmaston and Pasteur, 1972; Foster et al., 2001) and all samples were collected

252 above this elevation. Some samples featured a patchy cover of lichen or moss ( $\leq 2 \mathrm{~cm}$ thick) and

253 we avoided this where possible, although we note that a persistent cover of moss of $2 \mathrm{~cm}$

254 thickness would alter the resultant exposure ages by < 2\% (Dunai, 2010; Plug et al., 2007). We

255 also did not correct ${ }^{10} \mathrm{Be}$ ages for the potential influence of erosion, as samples did not show

256 evidence that could be used to estimate quantitatively surface erosion rates. Previous applications

257 of ${ }^{10} \mathrm{Be}$ dating in the Rwenzori suggest that raised quartz veins and rock surfaces on single

258 moraine crests yield statistically similar ages (Jackson et al., 2019). 


\begin{tabular}{|c|c|c|c|c|c|c|c|c|}
\hline \multicolumn{9}{|c|}{ Table 3: Rwenzori Surface-Exposure Ages } \\
\hline \multicolumn{9}{|c|}{ Bujuku Valley } \\
\hline Map ID & Sample ID & Landform & Age (St) & \pm (int; St) & $\pm(e x t ; S t)$ & Age (LSDn) & \pm (int; LSDn) & \pm (ext; LSDn) \\
\hline 1 & RZ-12-21 & Speke moraine & 360 & 30 & 40 & 370 & 30 & 40 \\
\hline 2 & $R Z-12-22$ & Speke moraine & 270 & 20 & 20 & 280 & 20 & 30 \\
\hline 3 & RZ-12-24 & Speke moraine & 400 & 20 & 30 & 410 & 20 & 30 \\
\hline 4 & $R Z-12-25$ & Speke moraine & 460 & 20 & 30 & 480 & 20 & 30 \\
\hline & & & & & & & & \\
\hline & & & & & & & & \\
\hline \multicolumn{9}{|c|}{ Nyamugasani Valley } \\
\hline Map ID & Sample ID & Landform & Age (St) & \pm (int; St) & $\pm(e x t ; S t)$ & Age (LSDn) & \pm (int; LSDn) & $\pm(e x t ; L S D n)$ \\
\hline 5 & RZ-15-10 & Perched boulder & 12130 & 120 & 690 & 11510 & 110 & 680 \\
\hline 6 & RZ-15-11 & Perched boulder & 11360 & 80 & 650 & 11010 & 80 & 640 \\
\hline 7 & RZ-15-09 & Perched boulder & 10920 & 120 & 630 & 10700 & 120 & 630 \\
\hline 8 & RZ-15-07 & Perched boulder & 4520 & 50 & 260 & 4980 & 50 & 290 \\
\hline 9 & RZ-15-08 & Perched boulder & 6520 & 120 & 390 & 6590 & 130 & 400 \\
\hline & & & & & & & & \\
\hline 10 & RZ-15-01 & Cirque Bedrock & 5010 & 60 & 290 & 5400 & 60 & 320 \\
\hline 11 & RZ-15-02 & Cirque Bedrock & 5040 & 60 & 290 & 5430 & 60 & 320 \\
\hline 12 & RZ-15-03 & Cirque Bedrock & 5680 & 50 & 320 & 5930 & 50 & 350 \\
\hline
\end{tabular}

Table 3. Cosmogenic ${ }^{10} \mathrm{Be}$ surface-exposure ages for samples from the Bujuku and Nyamugasani valleys. We report ages as calculated using both time-invariant ("St"; Lal, 1991; Stone, 2000) and time-variant ("LSDn"; Lifton et al., 2016) scaling with internal ("int") and external ("ext") error.

\section{Results}

\subsection{Bujuku valley}

We term the prominent Lac Gris stage moraine on the south-facing slope of Mt. Speke the 'Speke moraine' (Figures 2-3). The Speke moraine marks the first glacial deposit up valley of the Omurubaho-stage moraine dated to $\sim 11.7 \mathrm{ka}$ (Jackson et al., in review) and is $\sim 300 \mathrm{~m}$

273 elevation downslope from the 1958 CE glacier extent (Whittow, 1963). The Speke moraine is

274 also $\sim 1.5 \mathrm{~km}$ up valley of the $\sim 11.0 \mathrm{ka}$ landslide that dams Lake Bujuku (Cavagnaro, 2017). The

275 right- and left-lateral ridges of the Speke moraine are well preserved and have steep ice-contact

276 slopes with more fan-like, low-angle ice-distal slopes. Four samples from the right-lateral

277 ridge yield ${ }^{10} \mathrm{Be}$ ages between $\sim 0.46$ and $0.27 \mathrm{ka}(\mathrm{RZ}-12-21,22,24,25 ; \sim 4,050 \mathrm{~m}$ asl)(Table 1). 


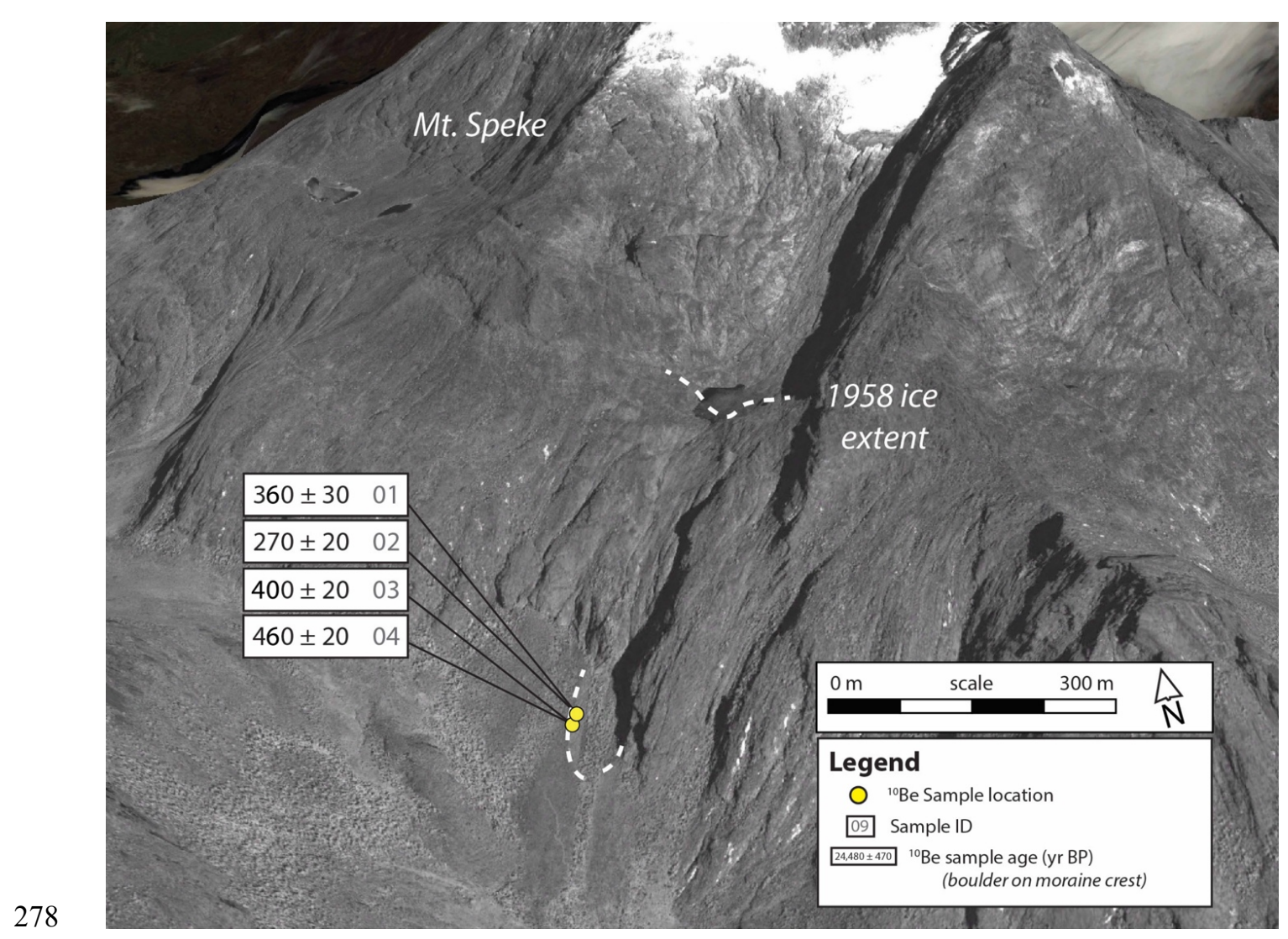

279 Figure 3. Mount Speke and ${ }^{10} \mathrm{Be}$ ages of the Speke moraine. Ages are shown in black with internal analytical 280 uncertainties. Sample ID numbers as in Tables 1-3 are shown in grey. The ice-contact slope of the Speke moraine is 281 outlined in dashed white, as is the documented 1958 ice margin 300 m upslope (Whittow et al., 1963). Sample 282 locations are mapped onto a 0.5 m-resolution Worldview-1 satellite image.

\subsection{Nyamugasani valley}

We dated five boulders on bedrock along an elevation transect on the south-facing slope

of Mt. Weisman (Figure 4, Tables 1-3). The transect extends from 4,400 to 4,490 m asl. All

287 samples are from glacially molded, sub-rounded boulders except for sample RZ-15-08 which is

288 from an angular boulder. Based on their size and position on the slope (i.e., away from the valley

289 walls where rockfall may occur), we presume these boulders were deposited by a receding

290 glacier. The two most down valley samples yield ${ }^{10} \mathrm{Be}$ ages of $12.1 \pm 0.1 \mathrm{ka}$ (RZ-15-10; 4,397m 

asl) and $11.4 \pm 0.1 \mathrm{ka}(\mathrm{RZ}-15-11 ; 4,400 \mathrm{~m}$ asl). A third sample is located $\sim 170 \mathrm{~m}$ up valley at $292 \sim 4,430 \mathrm{~m}$ asl and dates to $10.9 \pm 0.1 \mathrm{ka}$ (RZ-15-09). Approximately $250 \mathrm{~m}$ farther up valley at $293 \sim 4,490 \mathrm{~m}$ asl, two boulders on bedrock knobs yield ages of $4.5 \pm 0.0 \mathrm{ka}$ (RZ-15-07) and $6.5 \pm 0.1$ 294 ka (RZ-15-08).

295 In addition to the elevation transect of boulders on bedrock, we measured ${ }^{10} \mathrm{Be}$ 296 concentrations in three samples of the bedrock floor of the unoccupied cirque below the peak of 297 Mt. Weisman (4,509-4,536 m asl)(Figures 2, 4). We term this feature the 'Thomson cirque'. The 298 bedrock samples from Thomson cirque contain ${ }^{10} \mathrm{Be}$ concentrations between 1.94 and $2.03 \times 10^{-12}$ 299 atoms/gram (quartz), equivalent to 5.0-5.7 thousand years of exposure (RZ-15-01,02, 300 03)(Table 1,3).

301 


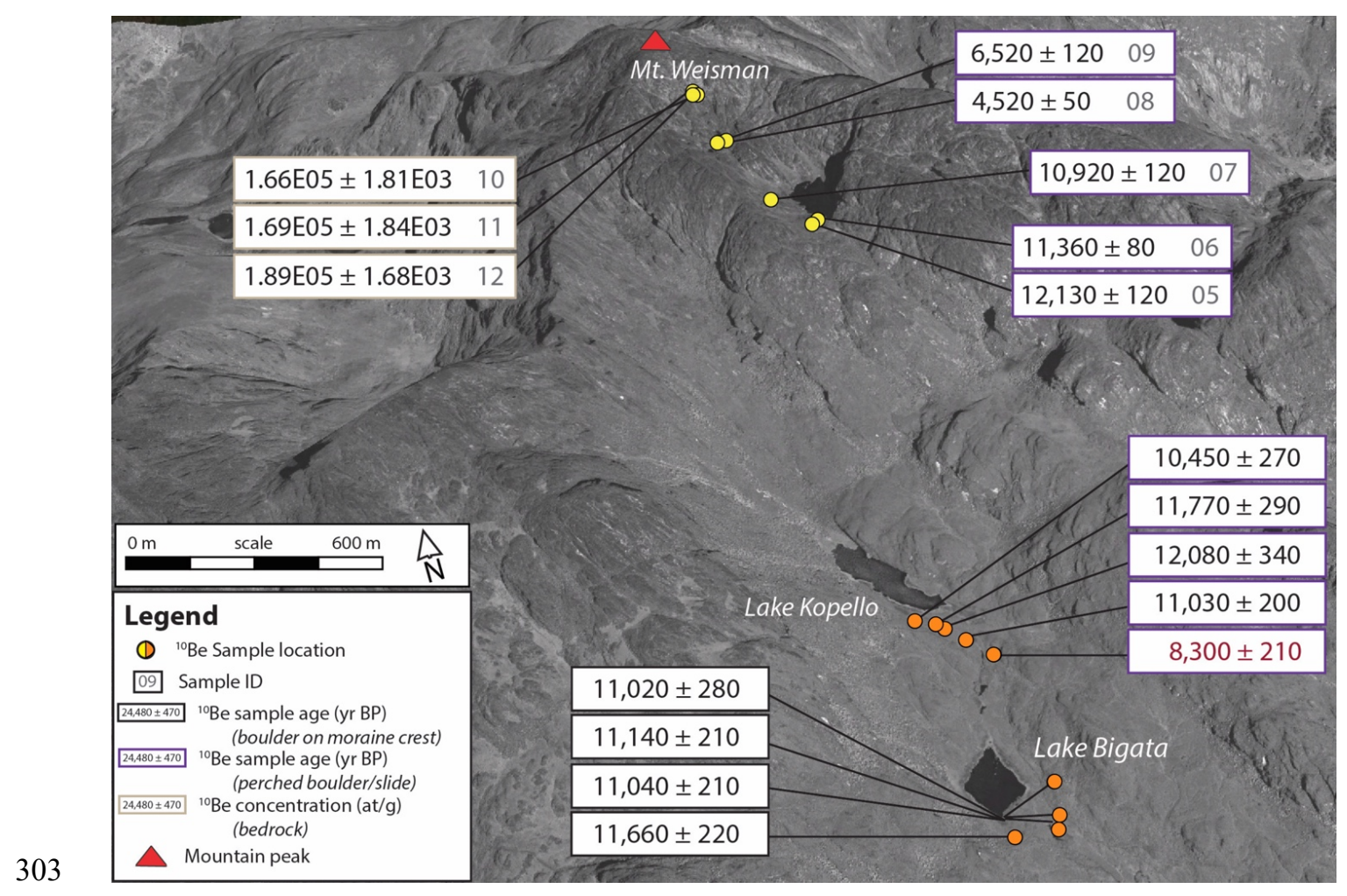

304 Figure 4. ${ }^{10} \mathrm{Be}$ ages and concentrations in the Nyamugasani valley. Ages are shown in black with internal analytical uncertainties. Sample ID numbers as in Tables 1-3 are shown in grey. Sample locations are marked by yellow circles and mapped onto a 0.5 -m resolution Worldview-1 satellite image. Previously reported ${ }^{10} \mathrm{Be}$ ages from the moraine that dams Lake Bigata and from boulders on bedrock near the outlet of Lake Kopello are marked with orange circles (Jackson et al., in review). Ages considered to be outliers are shown in red.

\section{Discussion}

\subsection{Holocene Glacial Fluctuations in the Rwenzori Mountains}

The ${ }^{10} \mathrm{Be}$ ages from the Bujuku and Nyamugasani valleys suggest that glaciers in both

313 catchments retreated rapidly during the Early Holocene. Based on the lack of glacial deposits in

314 the Bujuku valley between the $\sim 11.7$ ka moraine and the Speke moraine, and the $\sim 11.0 \mathrm{ka}$ age of

315 the landslide that dams Lake Bujuku (Cavagnaro, 2017), we suggest that the former Bujuku

316 valley glacier retreated up the valley at, or shortly after, the onset of the Holocene. The landslide

317 occurs $\sim 1.5 \mathrm{~km}$ up valley of the $\sim 11.7 \mathrm{ka}$ moraine and is undisturbed, indicating that ice had 
retreated at least this distance up valley by $\sim 11 \mathrm{ka}$ and that ice remained up valley of this site throughout the Holocene. Although it is possible that wetland or colluvium deposits on the valley floor buried additional glacial deposits, there are no lateral moraines higher on the valley walls and no evidence of glacial readvance over these colluvial sediments.

The morphology of the Speke moraine in the Bujuku valley, with steep ice-contact slopes and more gentle ice-distal slopes (Figure 2), indicates that the lateral ridges formed as rock-fall debris from the slopes of Mt. Speke fell onto the former Speke Glacier surface and was transported supraglacially to the ice margin. The deposition of this rock-fall debris along the glacier margins produced the fan-like ice-distal slopes of the Speke moraine. Deposition ceased when the glacier receded and the moraine was abandoned at $~ 270-460$ years ago.

Additional evidence for Early Holocene glacial recession in the Rwenzori comes from the Nyamugasani valley. The stratigraphically innermost moraine (i.e., farthest up valley) in the Nyamugasani valley dates to $\sim 11.2 \mathrm{ka}$ (Jackson et al., in review) (Figure 4). Approximately 0.5 $\sim 12.1$ and $10.5 \mathrm{ka}$ (Jackson et al., in review). An additional $\sim 1.6 \mathrm{~km}$ up valley from the Lake Kopello bedrock, glacially-transported boulders set down on bedrock yield ages between $\sim 12.1$ and $10.9 \mathrm{ka}$. Based on the statistical similarity of these sample ages, we interpret these samples to reflect rapid glacier recession from the innermost Nyamugasani valley moraine $(\sim 11.2 \mathrm{ka})$

336 during the Early Holocene. These data suggest that the valley was deglaciated to an elevation of $337 \sim 4,430 \mathrm{~m}$ asl by at least $\sim 10.9 \mathrm{ka}$.

338 Farther up valley, bedrock on the floor of Thomson cirque, below the south-facing peak 339 of Mt. Weisman, has ${ }^{10} \mathrm{Be}$ concentrations equivalent to $~ 5.0-5.7 \mathrm{ka}$ of net exposure (Figure 4).

340 The cirque was occupied by the former Thomson Glacier until at least the mid $20^{\text {th }}$ century 
341 (Meader, 1937; Whittow et al., 1963; Osmaston and Pasteur, 1972). This implies that the cirque

342 was ice-free for some period of time before its occupation by Thomson Glacier (Doughty et al.,

343 in press). If we assume that ice cover during the LGM (Kelly et al., 2014; Jackson et al., 2019)

344 was erosive enough to remove any pre-existing ${ }^{10} \mathrm{Be}$ from the bedrock surface, the measured

345 bedrock ${ }^{10} \mathrm{Be}$ concentrations reflect the total period of exposure of the bedrock (i.e., ice-free

346 conditions) after the LGM. More specifically, based on the Early Holocene age of moraines

347 down valley (Jackson et al., in review), we suggest the Thomson cirque bedrock ${ }^{10} \mathrm{Be}$

348 concentrations indicate the net duration of bedrock exposure ( 5.0-5.7 ka) during the Holocene.

349 This interpretation, and the observation that the cirque was occupied by Thomson Glacier

350 during the early and middle $20^{\text {th }}$ century, leads to one notable consequence. Namely, if the

351 Thomson cirque was ice-free for $~ 5.0-5.7 \mathrm{kyr}$ during the Holocene yet occupied by ice during at

352 least a portion of Late Holocene time, this implies that ice had ablated away completely in the

353 cirque at some point earlier in the Holocene before re-nucleating prior to the $20^{\text {th }}$ century. This

354 scenario may include multiple periods of glacial ablation and readvance, or a single period of

355 ice-free conditions followed by Late Holocene re-nucleation. Although the timing of ice

356 recession and re-nucleation within the cirque cannot be established with the data presented here,

357 the bedrock ${ }^{10} \mathrm{Be}$ concentrations suggest that the cirque remained ice-free for a significant portion

358 of the Holocene Epoch.

359 The two boulders on bedrock $\sim 10-20 \mathrm{~m}$ downslope of the cirque (dated to $\sim 4.5$ and 6.5

$360 \mathrm{ka}$; RZ-15-07, 08) suggest that the former Thompson Glacier extended to this downslope

361 location during the Middle Holocene. However, the ${ }^{10} \mathrm{Be}$ ages of these boulders are similar to the

362 exposure-age equivalent of the nearby cirque bedrock $(\sim 5.0-5.7 \mathrm{ka})$, which suggests that the

363 boulders may contain inherited ${ }^{10} \mathrm{Be}$. In this scenario, the boulders would have been plucked 
from the nearby cirque floor and transported a short distance $(\sim 100 \mathrm{~m})$ by the former Thomson

Glacier during a Late Holocene readvance. Alternatively, the boulders may have fallen onto the ice surface from the valley walls above and escaped sub-glacial erosion prior to deposition. Sample RZ-15-08 ( 6.5 ka) is from an angular boulder, which may indicate that it was transported supraglacially after falling onto the former ice surface from the valley headwall. In contrast, sample RZ-15-07 ( 4.5 ka) was sub-rounded in appearance and so was presumably eroded during glacial transport. These sampled boulders are located near the early- $20^{\text {th }}$ century snow or ice margin, as shown in photographs from 1937 CE (Meader, 1937). The proximity of the samples to the early $20^{\text {th }}$ century snow/ice margin supports the interpretation that the boulders were deposited during a Late Holocene advance of Thomson Glacier, but more data are needed to determine the depositional histories of these samples. Due to the uncertainties associated with these samples, we do not use their ${ }^{10} \mathrm{Be}$ ages in any subsequent interpretations. occurred in both catchments during the Early Holocene and that glaciers in these valleys then retreated to, or inboard of, their maximum late- $19^{\text {th }}$ or early-20 $0^{\text {th }}$ century extents (Figure 5). In the Nyamugasani valley, ${ }^{10} \mathrm{Be}$ concentrations measured in bedrock samples from the floor of Thomson cirque suggest 5-6 kyr of net exposure of surfaces that were glacierized in the first half of the $20^{\text {th }}$ century. The results do not preclude the possibility that glaciers persisted on the high Rwenzori peaks throughout the Holocene, albeit inboard of their late $19^{\text {th }}$ century positions.

383 However, the data suggest that glaciers in the Bujuku and Nyamugasani valleys did not advance 384 beyond their Late Holocene maximum ice positions during Early or Middle Holocene time. 


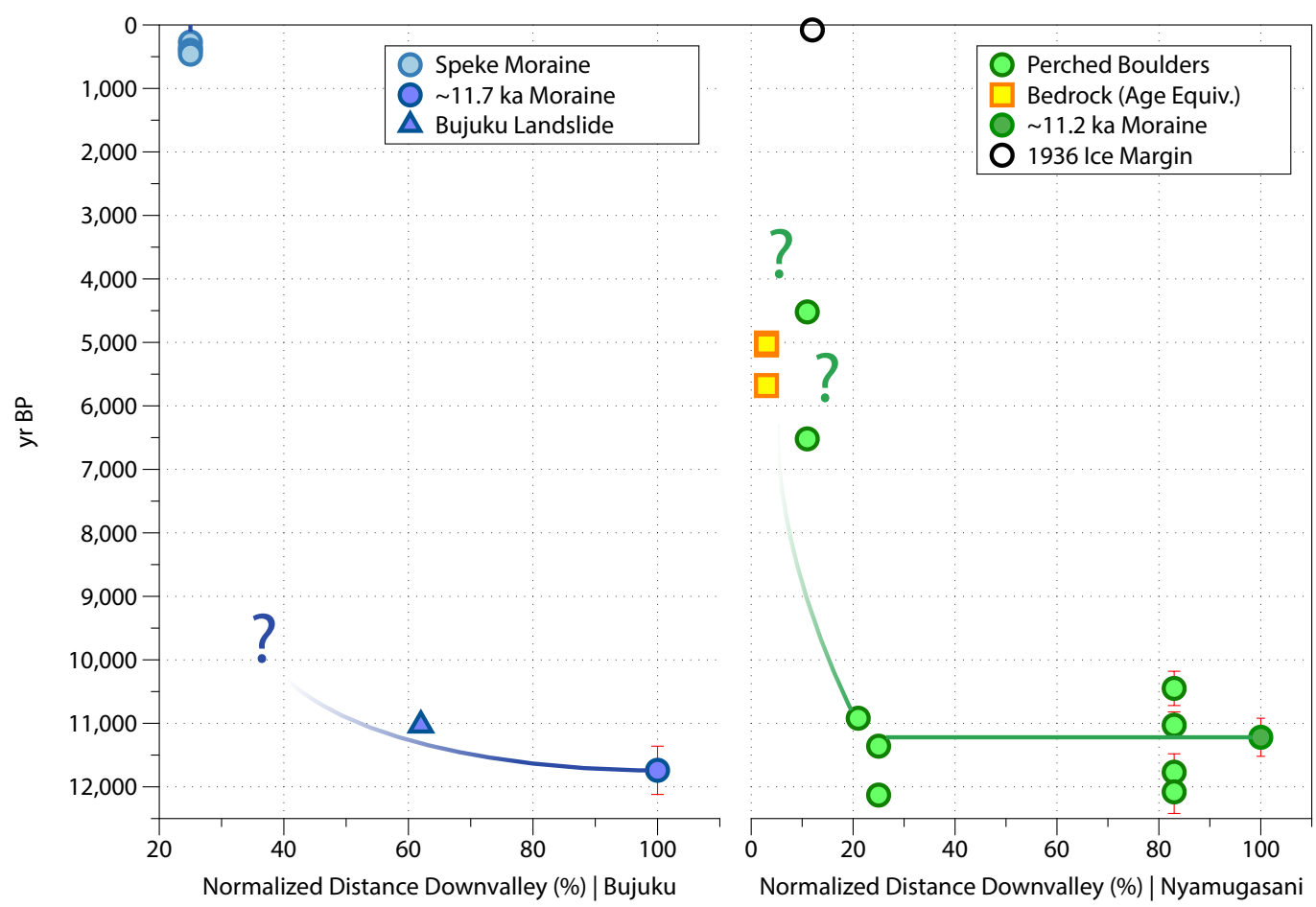

Figure 5. Normalized glacial extent in the Bujuku and Nyamugasani valleys during the Holocene. Lines indicate reconstructed glacial extent, question marks highlight periods where glacial extent is uncertain. (left) In the Bujuku valley, the maximum dated Holocene position ( $11.7 \mathrm{ka}$ moraine; Jackson et al., in review) is roughly $1.5 \mathrm{~km}$ down valley of the $\sim 11 \mathrm{ka}$ landslide which dams Lake Bujuku (Cavagnaro, 2017) and over $3 \mathrm{~km}$ down valley from the Speke moraine. (right) In the Nyamugasani valley, the most up valley moraine in the catchment dates to $\sim 11.2 \mathrm{ka}$. Boulders set down on the Kopello ridge yield ages between $\sim 12.1-10.5 \mathrm{ka}$. The Nyamugasani transect boulders yield similar ages to those on the Kopello ridge, but are $1.8 \mathrm{~km}$ farther up valley. Yellow squares mark the exposure-age equivalents $\left({ }^{10} \mathrm{Be}\right.$ concentration) of samples of bedrock from Thomson cirque, although we emphasize that these ages represent the cumulative exposure duration (likely since the LGM), and do not necessarily reflect the most recent period of exposure.

\subsection{Patterns of East African Glaciation and Temperature during the Holocene}

Although sensitive to precipitation, humidity, aspect, and hypsometry, glaciers in the 'humid' inner tropics $\left(\sim 10^{\circ} \mathrm{N}-10^{\circ} \mathrm{S}\right)$ are influenced primarily by temperature (e.g., Sagredo et al., 2014). This includes glaciers in the Rwenzori (Taylor et al., 2006; Russell et al., 2009; Kelly et al., 2014; Doughty et al., in press). The hypothesis that glacial fluctuations in the Rwenzori 
404 paleolimnological records of regional precipitation and temperature (Figure 6). Organic

405 geochemical (branched glycerol dialkyl glycerol tetraethers; brGDGTs) proxy temperature

406 records from four East African lakes and the Congo River Basin indicate temperatures warmed

407 by $\sim 1{ }^{\circ} \mathrm{C}$ from $\sim 12-11 \mathrm{ka}$, were similar to Late Holocene values from $\sim 11$ to $8 \mathrm{ka}$, and then rose

408 to a mid-Holocene thermal maximum between 6 and $5 \mathrm{ka}$, before cooling to Late Holocene

409 values (Ivory et al., 2017, and references therein). The Early Holocene is also marked by the

410 African Humid Period (AHP; 11.6-5.0 ka), a time of elevated precipitation across tropical

411 Africa (Garcin et al., 2007) reflected in precipitation reconstructions from Lakes Victoria and

412 Tanganyika, the Nile River Delta, and at the foot of the Rwenzori Mountains at Lake Edward

413 (Russell et al., 2003a; Buening and Russell, 2004; Tierney et al., 2008; Berke et al., 2012;

414 Weldeab et al., 2014). Declining precipitation associated with the end of the AHP began at 5.2

415 ka in western Uganda, recorded by rising salinity in Lake Edward (Russell et al., 2003b, Russell

416 and Johnson, 2006), roughly coincident with the onset of cooling in East Africa. Rwenzori

417 glaciers thus retreated during a wet and warming Early Holocene and remained near or inboard

418 of their Late Holocene maxima during the warm, drying Middle Holocene. The end of the AHP

419 and the onset of cooler conditions in East Africa broadly coincides with the transition to more

420 erosive glacial margins on Mt. Kenya (Karlen at el., 1999) and with the beginning of extended

421 net accumulation on the Kilimanjaro Ice Cap after 4 ka (Gabrielli et al., 2014). We suggest that

422 regional temperatures were sufficiently high during the Early and Middle Holocene to dominate

423 glacial mass balance in the African tropics in spite of elevated precipitation.

424 The pattern of Holocene glacial fluctuations inferred in the Rwenzori is broadly

425 consistent with reconstructed glacial histories from elsewhere in East Africa. In Ethiopia,

426 Uganda, and Kenya, glaciers retreated either during or prior to the Early Holocene (Hamilton and 
427 Perrot, 1982; Shanahan and Zreda, 2000; Tiercelin et al., 2008) and remained near or inboard of

428 reconstructed Late Holocene positions throughout Holocene time. Although disputed (Mahaney,

429 1989), there is some evidence for a Middle Holocene readvance of glaciers on Mt. Kenya

430 (Perrot, 1982; Johansson and Holmgren, 1985; Karlen et al., 1999). The ages of 4.5-6.5 ka of

431 perched boulders in the Rwenzori's Nyamugasani valley may indicate a similar Middle Holocene

432 readvance, but to a position near or inboard of the maximum Late Holocene extent (Meader,

433 1937; Osmaston and Pasteur, 1972). Acknowledging this uncertainty, we suggest that the

434 Rwenzori chronology is generally representative of Holocene glacial fluctuations in tropical

435 Africa.

436 Our comparison of Rwenzori glacier extents with regional GDGT-based temperature

437 records indicates that ice masses did not respond linearly to temperature. For example, GDGT

438 temperature reconstructions suggest regional temperatures at $\sim 11 \mathrm{ka}$ were similar to temperatures

439 at 1 ka-present (Ivory et al., 2017). In contrast, glacial margins during the Early Holocene were

$440 \sim 330 \mathrm{~m}$ lower in the Nyamugasani valley and 490 $\mathrm{m}$ lower in the Bujuku valley than during the

441 Late Holocene (Figure 6). This difference may be due to the fact that there was more substantial,

442 if retreating, ice volume in the Rwenzori at $\sim 11 \mathrm{ka}$ relative to the Late Holocene, and that Late

443 Holocene ice was re-nucleating or re-advancing after a period of sustained ablation.

444 Alternatively, this difference may reflect two distinct equilibrium glacial mass balances at

445 similar temperatures but with different precipitation regimes and radiative boundary conditions.

446 Modeling suggests that past changes in Rwenzori equilibrium-line altitude are only weakly

447 influenced by precipitation amount, and that the large ( $60 \%$ increase; Buening and Russell,

448 2004) changes in precipitation in western Uganda during the AHP are insufficient to explain the

449 large downslope movement of Rwenzori glaciers observed at $\sim 11 \mathrm{ka}$ (Doughty et al., in press). 
450 Early Holocene glacial recession is coincident with both increasing atmospheric $\mathrm{CO}_{2}\left(\mathrm{Monnin}^{\mathrm{et}}\right.$

451 al., 2001)(Figure 6), which increases surface longwave radiation, and with rising mean-annual

452 equatorial insolation after $\sim 10 \mathrm{ka}$ (Berger and Loutre, 1991). Because tropical glaciers undergo

453 ablation throughout the year, mean-annual radiation (both insolation and longwave) influences

454 glacial mass balance in the tropics (Kaser and Osmaston, 2002) and may have played a role in

455 Holocene glacial extents. However glaciers in the Rwenzori and elsewhere in East Africa

456 apparently re-nucleated or readvanced during the Late Holocene, whereas atmospheric $\mathrm{CO}_{2}$ and

457 mean annual insolation continued to rise. Alternatively, seasonal, rather than mean-annual,

458 insolation is another potential forcing mechanism for tropical glacial fluctuations. The sun passes

459 directly over the equator twice each year in September and March, coincident with the twice-

460 annual equatorial wet season (Sept.-Nov. and March-May) and the passage of the Intertropical

461 Convergence Zone over the equator (Singarayer and Burrough, 2015). Modeling studies of ice

462 cliffs on Kilimanjaro (Mölg et al., 2003a) and of modern Rwenzori glaciers (Mölg et al., 2003b)

463 suggest that a transition to more regionally arid conditions after $\sim 1880$ CE reduced cloud cover

464 and increased the amount of net annual solar radiation impacting glacier surfaces during dry

465 seasons, which may have encouraged further ablation after the initiation of recent Rwenzori

466 deglaciation 1870 CE (Russell et al., 2009). Neither of the Rwenzori dry seasons (June-Aug

467 and Dec-Feb) had insolation minima during Middle Holocene (Figure 6), and so the Late

468 Holocene re-nucleation or readvance of African glaciers is difficult to reconcile with this

469 mechanism. Elevated wet season (Sept.-Nov.) insolation could play a role, but Sept. and March

470 insolation trends counteract each other during the Holocene. More work is needed to determine

471 the discrete influences on glacial mass balance over millennial timescales during the Holocene in

472 the East African tropics. 
https://doi.org/10.5194/cp-2020-61

Preprint. Discussion started: 5 May 2020

(C) Author(s) 2020. CC BY 4.0 License.
Climate of the Past

Discussions

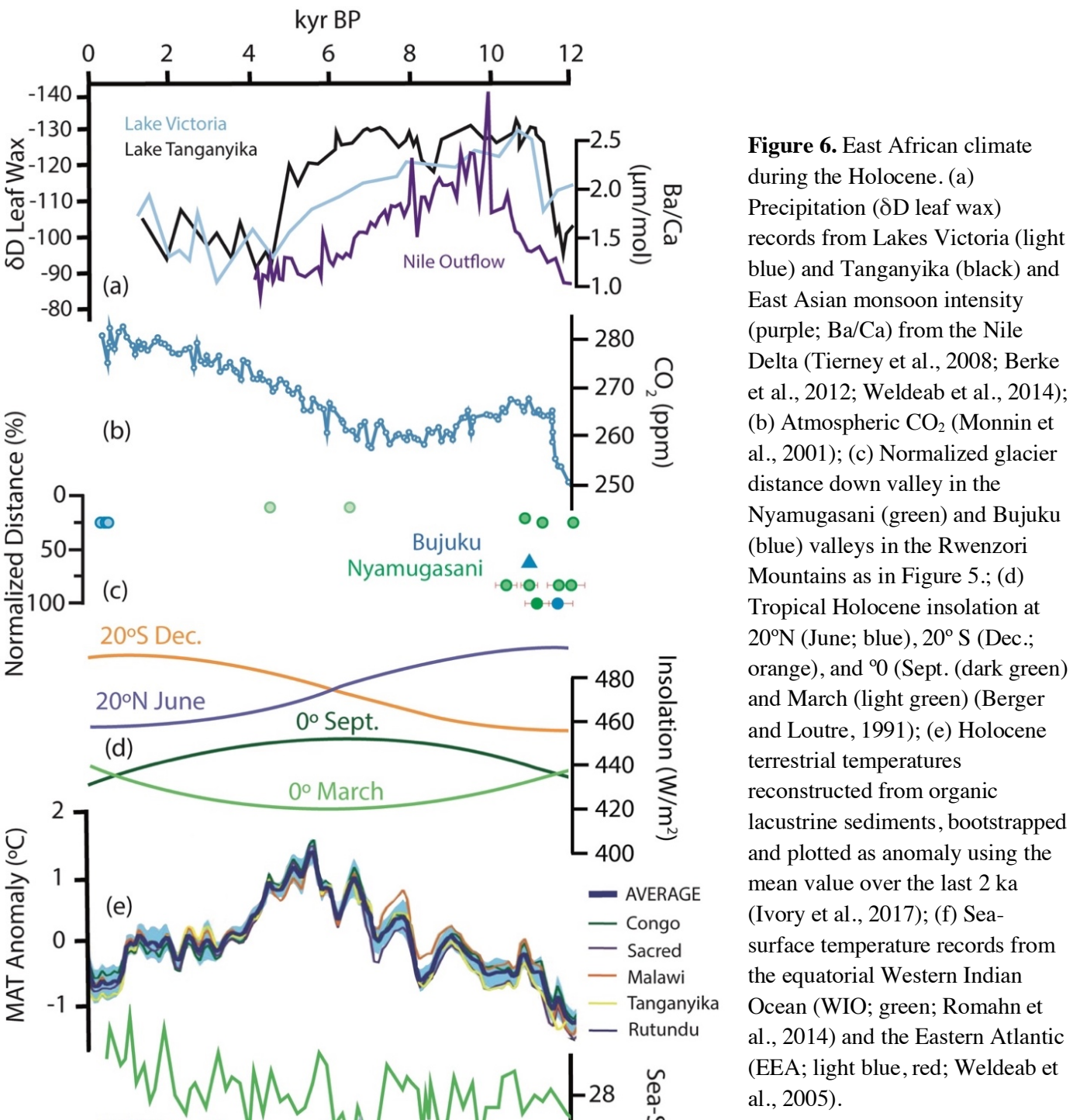




\subsection{Tropical South American Glacial Fluctuations and Implications for Holocene Climate}

Reconstructions of Holocene glacial fluctuations in South America show broad

515 similarities in the timing and magnitude of tropical Andean glacial extent change with records of

516 glacial extent from tropical Africa. Glaciers in the northern and southern tropical Andes retreated

517 during the Early Holocene and remained near or within their Late Holocene extents throughout

518 much of the Holocene Epoch (e.g., Jomelli et al., 2014; Stansell et al., 2017). ${ }^{10}$ Be dating of Late

519 Holocene moraines documents glacial advances in the South American tropics after $\sim 2-1 \mathrm{ka}$

520 (Solomina et al., 2015), and many glaciers only reached their Late Holocene maximum extents

521 within the last $~ 700-500$ years (Licciardi et al., 2009; Jomelli et al., 2011; Jomelli et al., 2014;

522 Stansell et al., 2015; 2017). Sediment-flux analyses and radiocarbon dating of glacially

523 influenced lake sediments, however, indicate that glaciers were more erosive, and perhaps more

524 extensive, after $\sim 5$ cal kyr BP relative to earlier Holocene time (e.g., Rodbell et al., 2008). Lake

525 sediment records from sites in the Eastern Cordillera and Cordillera Blanca of Peru suggest that

526 glaciers in these regions advanced and retreated multiple times during the Holocene, with more

527 advanced ice positions taking hold after 4-2 cal kyr BP (Rodbell et al., 2008; Stansell et al.,

$5282015 ; 2017) .{ }^{10} \mathrm{Be}$ dating and geomorphic mapping of moraines from these sites also suggest that

529 glaciers generally remained inboard of their Late Holocene maxima until at least $\sim 1$ ka (Stansell

530 et al., 2015; 2017). Altogether these data suggest that, after a period of Early Holocene retreat,

531 glacial margins in the South American tropics were more dynamic after $\sim 5$ ka relative to the

532 Early Holocene but did not achieve their maximum extents until after $\sim 1$ ka.

533 The broad similarity of Holocene glacial fluctuations in tropical East Africa and South

534 America suggests that tropical glaciers responded to a common, pan-tropical forcing mechanism

535 during the Holocene. Based upon prior observational and modeling work assessing controls on 
glacial mass balance across the South American Cordillera (Sagredo and Lowell, 2012; Sagredo et al., 2014), we suggest that temperature was the primary control on glacial extents across the low latitudes during the Holocene. This hypothesis requires that Holocene temperatures were similar across the tropics, and that whatever mechanism or mechanisms affected temperatures in one region had similar impact elsewhere. As in East Africa, radiative forcing from atmospheric $\mathrm{CO}_{2}$ and mean-annual or seasonal equatorial insolation cannot easily explain the pattern of glacial fluctuations in the South American tropics. This highlights an avenue for future research through both ground-based geologic investigation as well as through climate and mass-balance modeling. Determining the mechanisms that influence temperatures in the low latitudes is crucial for understanding better the context for modern warming and the sensitivity of tropical glaciers

546 to future climate change.

\section{Conclusions}

Twelve new ${ }^{10} \mathrm{Be}$ ages of glacial features in the Rwenzori Mountains indicate that glaciers retreated rapidly during the Early Holocene and remained near or within their Late Holocene extents through much of the Holocene Epoch. These results are broadly similar to records of past glacial fluctuations elsewhere in tropical East Africa. Based on a comparison of tropical East African glacial fluctuations with regional climate records, we suggest that temperature acted as the primary control on glacial fluctuations throughout the Holocene.

Holocene glacial recession was followed by a period of generally restricted ice extents until at

557 least $\sim 1 \mathrm{ka}$. The coherence of tropical African and South American glacial fluctuations suggests 
559 we suggest was most likely temperature. However the ultimate driver of Holocene temperatures,

560 and thus glacial extent, remains enigmatic. Understanding the controls on low-latitude

561 temperature is crucial for assessing and contextualizing modern climate variability and for

562 determining the sensitivity of tropical glaciers to changing climate conditions. Although more

563 work is needed to assess the sensitivity of low-latitude temperature to discrete forcing

564 mechanisms, the results presented here highlight the utility of glacial records in assessing past

565 terrestrial temperature change in tropical regions. 
583 All analytical information and metadata associated with newly reported cosmogenic nuclide measurements are included within the manuscript tables (Tables 1-3). All reported cosmogenic nuclide ages are as calculated using the ICE-D calibration database (calibration.ice-d.org) and version 3 of the online exposure-age calculator as described by Balco et al., 2008 and subsequently updated (hess.ess.washington.edu).

\section{Author Contribution}

$\mathrm{MK}, \mathrm{JR}$, and $\mathrm{AD}$ designed the project. $\mathrm{BN}$ coordinated the project in Uganda. MJ, AD, JR, and

MK collected samples. MJ and JH processed samples for ${ }^{10} \mathrm{Be}$ dating and SRHZ measured beryllium ratios. MJ, MK, AD, and JR analyzed results. MJ wrote the paper with contributions from all authors.

\section{Competing Interests}

596 The authors declare that they have no competing interests.

\section{Acknowledgements}

We thank the Uganda Wildlife Authority and the Uganda National Council on Science and

600 Technology for their support of and assistance with this project. We also thank Rwenzori

601 Mountaineering Services and Rwenzori Trekking Services for their logistical support while in

602 the field. Laura Hutchinson and David Cavagnaro helped process samples. This project was

603 supported by the National Science Foundation (EAR-1702293; GSS-1558358), Comer Science

604 and Education Foundation (CP103), Comer Global Climate Change Foundation (GCCF13), and 
https://doi.org/10.5194/cp-2020-61

Preprint. Discussion started: 5 May 2020

(c) Author(s) 2020. CC BY 4.0 License.

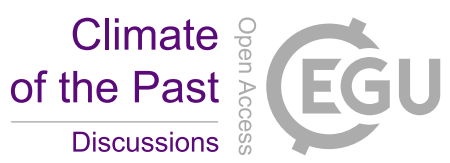

605 Sigma Xi (G20141015664263). Satellite imagery was granted by the DigitalGlobe Foundation

606 (0054508271). This is LLNL-JRNL-807478.

607

608

609

610

611

612

613

614

615

616

617

618

619

620

621

622

623

624

625

626

627 
Abruzzi, L.: The snows of the Nile. Geographic Journal, pp. 121-147. 1907.

Balco, G., Stone, J.O., Lifton, N.A. and Dunai, T.J.: A complete and easily accessible means of calculating surface exposure ages or erosion rates from ${ }^{10} \mathrm{Be}$ and ${ }^{26} \mathrm{Al}$ measurements. Quaternary Geochronology 3, 174-195. 2008.

Berger, A. and Loutre, M.F.: Insolation values for the climate of the last 10 million years. Quaternary Science Reviews 10, 297-317. 1991.

\section{Bergström, E.: British Ruwenzori Expedition, 1952 Glaciological Observations-Preliminary} Report. Journal of Glaciology 2, 469-476. 1955.

Berke, M.A., Johnson, T.C., Werne, J.P., Grice, K., Schouten, S. and Damsté, J.S.S.: Molecular records of climate variability and vegetation response since the Late Pleistocene in the Lake Victoria basin, East Africa. Quaternary Science Reviews 55, 9-74. 2012.

Bradley, R.S., Vuille, M., Diaz, H.F. and Vergara, W.: Threats to water supplies in the tropical Andes. Science 312, 1755-1756. 2006.

Beuning, K.R.M. and Russell, J.M. Vegetation and sedimentation in the Lake Edward basin, Uganda-Congo during the late Pleistocene and early Holocene.: Journal of Paleolimnology 32, 1-18. 2004.

Cavagnaro, D.B.: Cosmogenic ${ }^{10} \mathrm{Be}$ exposure dating of a post-glacial landslide in the Rwenzori Mountains, Uganda. Undergraduate thesis, Dartmouth College, Hanover NH, United States. 36 pp. 2017.

Chevallier, P., Pouyaud, B., Suarez, W. and Condom, T.: Climate change threats to environment in the tropical Andes: glaciers and water resources. Regional Environmental Change 11, 179187. 2011.

Doughty, A.M., Kelly, M.A., Russell, J.M., Jackson, M.S., Anderson, B.M., Chipman, J., Nakileza, B., and Dee, S.G.: The dynamics of Equilibrium Line Altitudes in over the past 31,000 years in the Rwenzori Mountains, East Africa. GSA Special Paper on Quaternary Science in honor of Prof. Stephen C. Porter [in press].

Dunai, T.J.: Cosmogenic Nuclides: Principles, concepts and applications in the Earth surface sciences. Cambridge University Press. 2010.

Foster, P.: The potential negative impacts of global climate change on tropical montane cloud forests, Earth Science Reviews 55, 73-106. 2001. 
674 Garcin, Y., Vincens, A., Williamson, D., Buchet, G., and Guiot, J.: Abrupt resumption of the 675 African Monsoon at the Younger Dryas-Holocene climatic transition. Quaternary Science 676 Reviews 26, 690-704. 2007.

Johansson, L., and Holmgren, K.: Dating of a moraine on Mount Kenya. Geografiska Annaler

Jackson, M.S., Kelly, M.A., Russell, J.M., Doughty, A.M., Howley, J.A., Cavagnaro, D.B., Zimmerman, S.R.H., and Nakileza, B.: Glacial fluctuations in tropical Africa during the last glacial termination and implications for tropical climate following the Last Glacial Maximum. Quaternary Science Reviews [in review].

Jackson, M.S., Kelly, M.A., Russell, J.M., Doughty, A.M., Howley, J.A., Chipman, J.W., Cavagnaro, D., Nakileza, B. and Zimmerman, S.R.: High-latitude warming initiated the onset of the last deglaciation in the tropics. Science Advances, 5(12), eaaw2610. 2019. Kilimanjaro unprecedented in the Holocene? The Holocene 20, 1079-1091. 2010.

Jomelli, V., Khodri, M., Favier, V., Brunstein, D., Ledru, M.-P., Wagnon, P., Blard, P.-H., Sicart, J.-E., Braucher, R., Grancher, D., Bourlès, D.L., Braconnot, P., and Vuille, M.: Irregular tropical glacier retreat over the Holocene epoch driven by progressive warming. Nature 474, 196-199. 2011.

Jomelli, V., Favier, V., Vuille, M., Braucher, R., Martin, L., Blard, P.-H., Colose, C., Brunstein, D., He, F., Khodri, M., Bourlès, D.L., Leanni, L., Rinterknecht, V., Grancher, D., Francou, B., Ceballos, J.L., Fonseca, H., Liu, Z., and Otto-Bleisner, L.: A major advance of tropical Andean glaciers during the Antarctic cold reversal. Nature 513, 224-228. 2014.

Karlén, W., Fastook, J.L., and Holmgren, K.: Glacier Fluctations on Mount Kenya since-6000 Cal. Years BP: Implications for Holocene Climatic Change in Africa. Ambio 28, 409-418. 1999.

Kaser, G. and Osmatson, H. Tropical Glaciers. Cambridge, Cambridge University Press, 207 pp. 2002. 
707 Kelly, M.A.: The Late Würmian Age in the Western Swiss Alps: Last Glacial Maximum (LGM) 708 Ice-surface Reconstruction and ${ }^{10} \mathrm{Be}$ Dating of Late-glacial Features. PhD thesis, University of

709 Bern, Switzerland. 2003.

710 Kelly, M.A., Russell, J.M., Baber, M.B., Howley, J.A., Loomis, S.E., Zimmerman, S., Nakileza, 711 R., and Lukaye, J. Expanded glaciers during a dry and cold Last Glacial Maximum in equatorial 712 East Africa. Geology 42, 519-522. 2014.

713 Kelly, M.A., Lowell, T.V., Applegate, P.J., Phillips, F.M., Schaefer, J.M., Smith, C.A., Kim, H., 714 Leonard, K.C., Hudson, A.M.: A locally calibrated, late glacial ${ }^{10}$ Be production rate from a low715 latitude, high-altitude site in the Peruvian Andes. Quaternary Geochronology 26, 1-16. 2015.

716 Lal, D.: Cosmic ray labeling of erosion surfaces: in situ nuclide production rates and erosion 717 models. Earth and Planetary Science Letters 104, 424-439. 1991.

718 Licciardi, J.M., Schaefer, J.M., Taggart, J.R., and Lund, D.C.: Holocene Glacier Fluctuations in 719 the Peruvian Andes Indicate Northern Climate Linkages. Science 325, 1677-1679. 2009.

Lifton, N.: Implications of two Holocene time-dependent geomagnetic models for cosmogenic

721 nuclide production rate scaling. Earth and Planetary Science Letters 433, 257-268. 2016.

722 Livingstone, D.A.: Postglacial vegetation of the Ruwenzori Mountains in equatorial Africa.

723 Ecological Monographs 37, 25-52. 1967.

724 Loomis, S.E., Russell, J.M., Ladd, B., Street-Perrott, F. A., and Sinninghe Damsté, J.S.:

725 Calibration and application of the branched GDGT temperature proxy on East African lake

726 sediments. Earth and Planetary Science Letters 375-378, 277-288. 2012.

727 Loomis, S.E., Russell, J.M., Verschuren, D., Morrill, C., De Cort, G., Damsté, J.S.S., Olago, D., 728 Eggermont, H., Street-Perrott, F.A., and Kelly, M.A.: The tropical lapse rate steepened during 729 the Last Glacial Maximum. Science Advances 3, e1600815. 2017.

730 Mahaney, W.C., e.d. Quaternary and Environmental Research on East African Mountains. CRC 731 Press. 1989.

732 McConnell, R.B.: Outline of the geology of the Ruwenzori Mountains, a preliminary account of 733 the results of the British Ruwenzori expedition, 1951-1952. Overseas Geology and Mineral

734 Resources 7, 245-268. 1959.

735 McGlynn, G., Mackay, A.W., Rose, N.L., Taylor, R.G., Leng, M.J. and Engstrom, D.R.:

736 Palaeolimnological evidence of environmental change over the last 400 years in the Rwenzori

737 Mountains of Uganda. Hydrobiologia 648, 109-122. 2010.

738 Meader, M., 1937. From the University of Wisconsin Milwaukee AGSL Photo Library

739 [https://collections.lib.uwm.edu/digital/collection/agsafrica/id/358/rec/102] 
740 Mölg, T., Hardy, D.R. and Kaser, G.: Solar-radiation-maintained glacier recession on

741 Kilimanjaro drawn from combined ice-radiation geometry modeling. Journal of Geophysical

742 Research: Atmospheres 108 (D23). 2003a

Mölg, T., Georges, C., and Kaser, G.: The contribution of increased incoming shortwave

744 radiation to the retreat of the Rwenzori glaciers, East Africa, during the 20th century.

745 International Journal of Climatology 23, 291-303. $2003 \mathrm{~b}$.

Monnin, E., Indermühle, A., Dällenbach, A., Flückiger, J., Stauffer, B., Stocker, T.F., Raynaud, D., and Barnola, J.M.: Atmospheric $\mathrm{CO}_{2}$ concentrations over the last glacial termination. Science

$748 \quad 291,112-114.2001$.

Nishiizumi, K., Imamura, M., Caffee, M.W., Southon, J.R., Finkel, R.C., and McAninch, J.: Research Section B 285B, 403-413. 2007. layers and soils at Kilimanjaro's Northern Ice Field. The Holocene 24, 1398-1405. 2014.

Osmaston, H.: The past and present climate and vegetation of the Ruwenzori and its neighborhood. Ph.D. Thesis, Oxford University. 140 pp. 1965.

Osmaston, H.A. and Pasteur, D.: Guide to the Ruwenzori. Alden Press, Oxford, pp. 200. 1972.

Osmaston, H.: Glaciers, glaciations, and equilibrium line altitudes on the Rwenzori. In Mahaney, W.C. (Ed.) Quaternary and environmental research on East African mountains. Rotterdam,

759 Balkema, 31-104. 1989.

Perrott, R.A.: A high altitude pollen diagram from Mount Kenya: Its implications for the history of glaciation. In Coetzee J.A. and van Zinderen Bakker, E.M. (eds). Paleoecology of Africa 14,

$762 \quad 77-83.1982$.

Plug, L.J., Gosse, J.C., McIntosh, J.J., and Bigley, R.: Attenuation of cosmic ray flux in temperate forest. Journal of Geophysical Research 112, F02022. 2007. framework and possible role of glaciations. Tectonics 27. 2008. 

lithostratigraphic and paleohydrologic record from equatorial Africa: Lake Edward, UgandaCongo. Palaeogeography, Palaeoclimatology, Palaeoecology 193, 25- 49. 2003a.

Russell, J.M., Johnson, T.C., and Talbot, M.R.: A 725 yr cycle in the climate of central Africa during the Late Holocene. Geology 31, 677-680. 2003 b.

Russell, J.M. and Johnson, T.C.: The water balance and stable isotope hydrology of Lake Edward, Uganda-Congo. Journal of Great Lakes Research 32, 77-90. 2006.

Russell, J.M., Eggermont, H.E., Taylor, R., and Verschuren, D.: Paleolimnological records of recent glacier recession in the Rwenzori Mountains, Uganda-D.R. Congo. Journal of

783 Paleolimnology 41, 253-271. 2009.

Sagredo, E.A. and Lowell, T.V.: Climatology of Andean glaciers: A framework to understand glacier response to climate change. Global and Planetary Change 86-87, 101-109. 2012.

Sagredo, E.A., Rupper, S., and Lowell, T.V.: Sensitivities of the equilibrium line altitude to temperature and precipitation changes along the Andes. Quaternary Research 81, 355-366. 2014.

Schaefer, J.M., Kaplan, M., Putnam, A., and Schlüchter, C.: Southern mid-latitude terminations of MIS-4, the Last Glacial Maximum and the Late Glacial period in the New Zealand moraine record. Geochimica et cosmochimica acta 73, 29-29. 2009.

Shanahan, T. and Zreda, M.: Chronology of Quaternary glaciations in East Africa. Earth and Planetary Science Letters 177, 23-42. 2000.

Singarayer, J.S. and Burrough, S.L.: Interhemispheric dynamics of the African rainbelt during the late Quaternary. Quaternary Science Reviews 124, 48-67. 2015.

Solomina, O.N., Bradley, R.S., Hodgson, D.A., Ivy-Ochs, S., Jomelli, V., Mackinstosh, A.N., Nesje, A., Owen, L.A., Wanner, H., Wiles, G.C., and Young, N.E.: Holocene glacier fluctuations. Quaternary Science Reviews 111, 9-34. 2015.

Stansell, N.D., Rodbell, D.T., Licciardi, J.M., Sedlak, C.M., Schweinsberg, A.D., Huss, E.G., G36735.1-4. 2015.

803 Stansell, N.D., Licciardi, J.M., Rodbell, D.T., and Mark, B.G.: Tropical ocean- atmospheric 804 forcing of Late Glacial and Holocene glacier fluctuations in the Cordillera Blanca, Peru.

805 Geophysical Research Letters 44, 4176-4185. 2017.

806 Stocker, T.F., Qin, D., Plattner, G.K., Tignor, M., Allen, S.K., Boschung, J., Nauels, A., Xia, Y., 807 Bex, V., and Midgley, P.M.: IPCC, 2013: Climate Change 2013: The Physical Science Basis. 
808 Contribution of Working Group I to the Fifth Assessment Report of the Intergovernmental Panel 809 on Climate Change, 1535 pp. 2013.

810 Stone, J.O.: Air pressure and cosmogenic isotope production. Journal of Geophysical Research 811 105, 23753-23759. 2000.

812 Taylor, R.G., Mileham, L., Tindimugaya, C., Majugu, A., Muwanga, A., and Nakileza, B.:

813 Recent glacial recession in the Ruwenzori Mountains of East Africa due to rising air

814 temperature. Geophysical Research Letters 33, L10402. 2006.

815 Thompson, L.G., Mosley-Thompson, E., Davis, M.E., Henderson, K.A., Brecher, H.H., 816 Zagorodnov, V.S., Mashiotta, T.A., Lin, P.N., Mikhalenko, V.N., Hardy, D.R., and Beer, J.:

817 Kilimanjaro ice core records: Evidence of Holocene climate change in tropical Africa. Science

818 298, 589-593. 2002.

819 Thompson, L.G., Mosley-Thompson, E., Davis, M., and Mountain, K.: A paleoclimatic 820 perspective on the $21^{\text {st }-c e n t u r y}$ glacier loss on Kilimanjaro, Tanzania. Annals of Glaciology 52 , $821 \quad 60-68.2011$.

Tiercelin, J.J., Gibert, E., Umer, M., Bonnefille, R., Disnar, J.R., Lézine, A.M., HureauMazaudier, D., Travi, Y., Keravis, D., and Lamb, H.F.: High-resolution sedimentary record of the last deglaciation from a high-altitude lake in Ethiopia. Quaternary Science Reviews 27, 449467. 2008.

Tierney, J.E., Russell, J.M., Huang, Y., and Damsté, J.: Northern hemisphere controls on tropical southeast African climate during the past 60,000 years. Science 322, 252-255. 2008. change and tropical Andean glaciers: Past, present and future. Earth-Science Reviews 89, 79-96. 8302008.

Walker, M.J., Berkelhammer, M., Björck, S., Cwynar, L.C., Fisher, D.A., Long, A.J., Lowe, J.J., Newnham, R.M., Rasmussen, S.O. and Weiss, H.: Formal subdivision of the Holocene Series/Epoch: a Discussion Paper by a Working Group of INTIMATE (Integration of ice-core, marine and terrestrial records) and the Subcommission on Quaternary Stratigraphy (International Commission on Stratigraphy). Journal of Quaternary Science 27, 649-659. 2012.

839 Weldeab, S., Schneider, R.R., Kölling, M., and Wefer, G.: Holocene African droughts relate to 840 eastern equatorial Atlantic cooling. Geology 33, 981-984. 2005.

841 Weldeab, S., Menke, V., and Schmiedl, G.: The pace of East African monsoon evolution during 842 the Holocene. Geophysical Research Letters 41, 1724-1732. 2014. 
https://doi.org/10.5194/cp-2020-61

Preprint. Discussion started: 5 May 2020

(c) Author(s) 2020. CC BY 4.0 License.

843 Whittow, J.B., Shepherd, A., and Goldthorpe, J.E.: Observations on the glaciers of the 844 Ruwenzori. Journal of Glaciology 4, 581-616. 1963.

845 Woltering, M., Johnson, T.C., Werne, J.P., Schouten, S., and Damsté, J.S.S.: Late Pleistocene 846 temperature history of Southeast Africa: a TEX86 temperature record from Lake Malawi.

847 Palaeogeography, Palaeoclimatology, Palaeoecology 303, 93-102. 2011. 